\title{
Peningkatan Kemampuan Menulis Permulaan Siswa Menggunakan Media Gambar Flash Card dengan Pendekatan Saintifik Kelas li
}

\author{
Ade Prabowo ${ }^{1}$,Junaidi Indrawadi ${ }^{1}$, Ulil Amrii ${ }^{3}$ \\ ${ }^{1}$ Program Studi Pendidikan Guru Sekolah Dasar, Universitas Negeri Padang \\ ${ }^{3}$ SDN 13 Kapalo Koto, Kota Padang \\ e-mail: adeprabowo996@gmail.com,Junaidi.indra@fis.unp.ac.id, \\ ulilamritanjung@gmail.com
}

\begin{abstract}
Abstrak
Berdasarkan hasil observasi yang dilakukan di kelas II SDN 13 Kapalo Koto bahwa kemampuan menulis permulaan siswa masih rendah maka perlunya peningkatan kemampuan menulis permulaaan siswa dengan menggunakan media gambar Flash Card dengan pendekatan saintifik. Penelitian ini termasuk jenis penelitian tindakan kelas (classroom action research) dengan subjek penelitian siswa kelas II SDN 13 Kapalo Koto, Padang tahun ajaran 2021/2022 yang berjumlah 26 siswa. Penelitianini dilaksanakan dalam dua siklus dan setiap siklus memiliki empat komponen yaitu perencanaan, tindakan dan observasi, serta refleksi. Teknik penilaian berbentuk tes menulis permulaan menulis kalimat kata sapaan tema fabel dan keberagaman, secara sederhana dengan bahasa tulis. Teknik analisis data dalam penelitian ini menggunakan analisis deskriptif kualitatif dan analisis deskriptif kuantitatif. Indikator keberhasilan penelitian ini ditandai dengan meningkatnya kemampuan menulis permulaan menulis kalimat kata sapaantema fabel dan keberagaman secara sederhana dengan bahasa tulis siswa yang ditandai dengan $80 \%$ siswa mencapai KKM yang telah ditetapkan. Hasil dari penelitian ini menunjukkan bahwa penggunaan media gambar Flash Card dengan pendekatan saintifik terbukti mampumeningkatkankemampuan menulis permulaan siswa kelas 2 SDN 13 Kapalo Koto. Peningkatan tersebut dapat dilihat dari rata-rata nilai hasil evaluasi siswa yang mengalami peningkatan pada setiap pertemuannya. Rata-rata hasiltes menulis pada pra tindakan sebesar 61,15 . Siklus I rata-rata siswa meningkat menjadi 71,00 . Peningkatan rata-rata hasil evaluasi menulis permulaan siswa dari pra tindakan ke siklus I sebesar 9,85. Pada siklus II rata-rata hasil evaluasi siswa meningkat menjadi 82,03. Hal itu menunjukkan bahwa rata-rata hasil evaluasi siswa meningkat lagi sebesar 11,03.
\end{abstract}

Kata Kunci: menulis permulaan, gambar Flash Card

\begin{abstract}
Based on the results of observations made in class II SDN 13 Kapalo Koto that students' initial writing ability is still low, it is necessary to increase students' initial writing skills by using Flash Card image media with a scientific approach. This research belongs to the type of classroom action research with the research subjects being the second grade students of SDN 13 Kapalo Koto, Padang in the $2021 / 2022$ academic year, totaling 26 students. This research was conducted in two cycles and each cycle has four components, namely planning, action and observation, and reflection. The assessment technique is in the form of a writing test at the beginning of writing greeting sentences on the theme of fables and diversity, simply in written language. The data analysis technique in this study used qualitative descriptive analysis and quantitative descriptive analysis. The indicator of the success of this research is indicated by the increase in writing ability to begin writing greeting sentences for fable themes and simple diversity with students' written language which is marked by $80 \%$ of students achieving the predetermined KKM. The results of this study indicate that the use of Flash Card image media with a scientific approach is proven to be able to improve the initial writing ability of 2 nd grade students of SDN 13 Kapalo Koto. This increase can be seen from the average value of student evaluation results which has increased at each meeting. The average result of the pre-action writing test was 61.15 . In the first cycle, the students' average increased to 71.00 . The average increase in the students' initial writing evaluation results from pre-action to cycle I was 9.85 .
\end{abstract}


In the second cycle the average student evaluation results increased to 82.03 . This shows that the average student evaluation results increased again by 11.03 .

Keywords: start writing, Flash Card drawing

\section{PENDAHULUAN}

Dalam mata pelajaran bahasa Indonesia, ada empat keterampilan yang harus dikuasai siswa, yaitu keterampilan menyimak, keterampilan membaca, keterampilan berbicara, dan keterampilan menulis. Keempat keterampilan tersebut harus dilatihkan sejak dini yaitu sejak SD kelas rendah.

Menurut Nurmayah Ida dkk. (2016). Menulis permulaan adalah dasar pengajaran pertama kali diajarkan guru kepada anak kelas satu dan dua atau yang berada pada kelas rendah. Sejalan dengan pengertian diatas menulis permulaan (beginning writing) kegiatan ini disebut dengan Hand Writing, yaitucara merealisasikan simbol-simbol bunyi dan menulisnya dengan baik. Tingkatan ini terkait dengan strategi atau cara mewujudkan simbol-simbolbunyi bahasa menjadi huruf-huruf yang dapat dikenali secara konkret.

Nurcahyanti, I., \& Umar Samadhy, F. (2014). Menulis permulaan diawalidari melatih siswa memegang alat tulis dengan benar, menarik garis, menulis huruf, suku kata, kata, kalimat sederhana dan seterusnya. Menulis lanjut dimulai dari menulis kalimat sesuai gambar, menulis paragraf sederhana, menulis karangan pendek dengan bantuan berbagai media dengan ejaan yang benar.

Menanggapi hal tersebut, untuk mengetahui pelaksanaan Pembelajaran di SDN 13 Kapalo Koto, peneliti melakukan observasi melalui daring bersama guru kelas II SDN 13 Kapalo Koto Padang, pada tanggal 19 Desember 2020. Peneliti menemukan bahwa dalam pelaksanaan pembelajaran kemampuan menulis permulaaan di sekolah dasar masih rendah dibawah KKM 80 . masih terlihat guru lebih aktif memberikan materi dalam proses pembelajaran dengan menerapkan metode ceramah dan diskusi kelompok yang kadang-kadang divariasikan dengan tanya jawab. Selain belum adanya penggunaan mediayang merangsang kemampuan menulis permulaan disekolah. KKM yang ditetapkan oleh Sekolah yaitu 80. Rendahnya hasil belajar siswa pada mata pelajaran Bahasa Indonesia terlihat pada tabel di bawah ini

Tabel 1. Nilai rata-rata Menulis semester 1 pada mata pelajaran Bahasalndonesia kelas II SDN 13 Kapalo Koto

\begin{tabular}{ccccccc}
\hline \multirow{2}{*}{$\begin{array}{c}\text { Jumlah } \\
\text { Siswa }\end{array}$} & Nilai rata-rata & \multirow{2}{*}{ KKM } & \multicolumn{2}{c}{ Tuntas } & \multicolumn{2}{c}{ Tidak Tuntas } \\
\cline { 4 - 6 } & & & Jumlah siswa & Persentase & Jumlah Siswa & Persentase \\
\hline 26 & 55,00 & 80 & 6 & $23 \%$ & 20 & $77 \%$ \\
\hline \multicolumn{3}{c}{ ( Sumber : Guru kelas II SDN 13 Kapalo Koto) }
\end{tabular}

Berdasarkan tabel di atas, diketahui bahwa terdapat $23 \%$ atau 6 dari 26 siswa yang mendapatkan nilai di atas KKM, sedangkan $77 \%$ atau 20 dari 26 siswa mendapat nilai di bawah KKM dengan nilai KKM yang sudah ditentukan adalah 80. Hasil tersebut menunjukkan bahwa menulis permulaan siswa di kelas tersebut belum memenuhi ketuntasan klasikal. Pada penelitian ini, yang akan dibahas adalah adalah keterampilan menulis, yang tentunya tidak kalah penting dengan keterampilan yang lain. Kemampuan menulis biasanya terintegrasi dalam proses pembelajaran. Setiap mata pelajaran pasti memiliki tugas sebagai latihan dan pengayaan. Hal tersebut sering dilakukan secara terintegrasi dengan keterampilan menulis. Oleh karena itu, kemampuan menulis berkaitan erat dengan berbagai bidang studi. Untuk dapat menguasai keterampilan dalam menulis maka perlu adanya pembelajaran menulis permulaan.

Mengajarkan menulis permulaan bukanlah hal yang mudah. Banyak siswa kelas II SD yang kemampuan menulis permulaannya masih rendah. Sebagian siswa kelas II SD masih kesulitan untuk memahamami materi menulis mermulaan yang disajikan guru secara abstrak. Tak mengherankan jika hal tersebut terjadi, karena tahapan berpikir mereka masih berada pada tahap operasional konkret. Selain itu, di kelas II SD, siswa baru terbiasa belajar untuk merangkai huruf 
menjadi kata atau kalimat. Sedangkan untuk kelas II SD tuntutan kompetensi yang harus dikuasai siswa lebih tinggi. Pembelajaran menulis permulaan di kelas II SDN sudah dituntut untuk menyatakan ide / pesan secara tertulis. Sedangkan tahap berpikir siswa kelas II SD masih berada pada tahap operasional konkret. Oleh karena itu banyak siswa kelas II SD menganggap pembelajaran menulis permulaan itu sulit. Oleh karena itu, peneliti akan mencoba melakukan perubahan dalam pembelajaran menulis permulaan. Peneliti akan menggunakan media pada saat pembelajaran menulis permulaan tersebut.

Penggunaan media pembelajaran akan membantu mengefektifkan proses pembelajaran dan penyampaian pesan pada materi pelajaran yang disampaikan. Menurut Nurmayah Ida dkk. (2016) "secara umum, manfaat media dalam proses pembelajaran adalah mempermudah interaksi antara guru dengan siswa sehingga kegiatan pembelajaran akan lebih efektif dan efisien". Dengan digunakannya media dalam proses pembelajaran guru bisa lebih mudah untuk menyampaikan materi yang diajarkan kepada siswa.

Salah satu media yang dapat dimanfaatkan adalah media Flash Card. Peneliti memilih Flash Card atau education card karena media gambar ini dapat menarik perhatian siswa saat pembelajaran. Flash Card merupakan media visual yang dapat memperlancar pemahaman, memperkuat ingatan serta menumbuhkan minat siswa dan memberikan hubungan antara isi materi 6 pelajaran dengan dunia nyata. Flash Card merupakan kartu-kartu bergambar yang dilengkapi kata-kata, diperkenalkan oleh Glenn Doman (Fatoni, 2009). Gambar-gambar pada Flash Card dikelompokkan antara lain: seri binatang, buah-buahan, pakaian, warna, bentuk-bentuk angka, dan sebagainya.

Gambar Flash Card berperan membantu mengkonkretkan materi yang tengah diajarkan. Dengan demikian, siswa diharapkan dapat meningkatkan keterampilan menulis permulaan dengan mengamati gambar Flash Card, kemudian menyusun gambar yaitu dengan mencari persamaan dan perbedaan yang ada didalam gambar, setelah itu siswa menafsirkan apa yang ada dalam gambar tersebut, siswa membuat konsep yakni berupa tulisan, menafsirkan apa yang ada dalam gambar.

Siswa menafsirkan apa yang ada dalam gambar tersebut, siswa membuat konsep yakni berupa tulisan. Kemudian siswa mengkomunikasikan tulisan tersebut dengan membacakannya di depan kelas. Dengan demikian, siswa diharapkan dapat mengembangkan keterampilan menulis permulaannya. Peneliti tertarik untuk melakukan penelitian dengan judul " Peningkatan Kemampuan Menulis Permulaan Siswa Menggunakan Media Gambar Flash Card Dengan Pendekatan Saintifik Kelas II SDN 13 Kapalo Koto.

\section{Keterampilan Menulis Permulaan}

Anak menulis dengan cara anak sendiri. Hal ini sebagai bukti bahwa anak sudah belajar menulis secara alami di rumah dan di masyarakat. Menulis permulaan adalah tujuan sementara yang kemudian diharapkan siswa akan berkembang dan menggunakan kemampuan menulisnya untuk menambah pengetahuan dan mengembangkan pribadinya lebih lanjut (Sabarti Akhdiah, 1991). Pembelajaran menulis permulaan difokuskan pada: penulisan huruf, penulisan kata, penulisan kalimat sederhana, dan penulisan tanda baca. Rofi'uddin dan Zuhdi (1999) juga mengemukakan menulis permulaan difokuskan pada penulisan huruf, penulisan kata, penggunaan kalimat sederhana, dan tanda baca (huruf capital, titik, koma, dan tanda tanya). Sedangkan Sabarti Akhadiah (1992) menyatakan bahwa siswa kelas II SD diharapkan dapat menulis permulaan dengan ejaan yang benar dan dapat menyatakan ide/ pesan secara tertulis.

Kemampuan menulis permulaan merupakan keterampilan yang harus dikuasai siswa sekolah dasar sejak dini, karena keterampilanmenulis permulaan merupakan keterampilan yang sangat mendasar bagi siswa sekolah dasar. Menulis permulaan merupakan keterampilan menulis yang diajarkan pada kelas rendah, yakni kelas I dan II sekolah dasar sebagai pembelajaran menulis pada tingkat dasar. Pengetahuan dan kemampuan yang diperoleh siswa padapembelajaran menulis permulaan tersebut akan menjadi dasar dalam peningkatan dan pengembangan kemampuan siswa pada jenjangselanjutnya. Pembelajaran menulis permulaan sebagai acuan dasar tersebut baik dan kuat, diharapkan hasil pengembangan keterampilan menulis sampai tingkat selanjutnya akan menjadi baik pula. 
Menulis merupakan kegiatan yang paling sering dilakukan oleh setiap orang. Menulis membutuhkan keterampilan khusus yang harus dapat dipelajari dan senantiasa dilatih. Menulis memerlukan keterampilan tambahan bahkan motivasi tambahan pula, hal inidikarenakan menulis bukan bakat karena tidak semua orang mampu untuk menulis (Susanto, 2013). Menulis merupakan kegiatan yang memerlukan kemampuan yang bersifat kompleks. Kemampuan yang diperlukan antara lain kemampuan berpikir secara teratur dan logis, kemampuan mengungkapkan pikiran atau gagasan secara jelas, dengan menggunakan bahasa yang efektif, dan kemampuan menerapkan kaidahtulis-menulis dengan baik.

Dari pernyataan tersebut ditegaskan, bahwa kemampuan menulis dapat diperoleh melalui proses yang panjang. Sebelum sampai pada tingkat mampu menulis, siswa harus mulai dari tingkat awal, tingkat permulaan, mulai dari pengenalan lambang-lambang bunyi. Pengetahuan dan kemampuan yang diperoleh pada tingkat permulaan pada pembelajaran menulis permulaan itu, akan menjadi dasar peningkatan dan pengembangan kemampuan siswa selanjutnya. Apabila dasar itu baik, kuat, maka dapat diharapkan hasil pengembangannya pun akan baik pula, dan apabila dasar itu kurang baik atau lemah, maka dapat diperkirakan hasil pengembangannya akan kurang baik juga.

\section{Saintifik}

Rusman (2015) menyatakan bahwa pembelajaran Saintifik adalah sebuah pendekatan pembelajaran yang menekankan pada aktivitas siswa melalui kegiatan mengamati, menanya, menalar, mencoba dan membuat jejaring pada kegiatan pembelajaran di sekolah. Pendekatan saintifik merupakan pendekatan yang berpusat kepadameliputi mengamati, menanya, mencoba, mengolah, menyajikan, menyimpulkan, dan mencipta. Pendapat tersebut sejalan dengan yang diungkapkan oleh Daryanto (2014), yaitu, mengamati, menanya, menalar, mencoba dan mengkomunikasikan.

\section{METODE PENELITIAN}

Penelitian ini menggunakan penelitian tindakan kelas (PTK)berdasarkan model spiral yang dikembangkan oleh Suharsimi Arikunto (2008). Dalam penelitian tindakan kelas peneliti sebagai subjek dan siswa sebagai objek yang diteliti. Dalam penelitian tindakan kelas modal utamanya yaitu untuk mewawancarai siswa, dan guru bidangstudi dan peneliti sebagai pengamat dalam penelitian tindakan kelas. Penelitian ini mengunakan pendekatan kualitatif dan kuantitatif dengan jenis penelitian tindakan kelas. Dengan menggabungkanbatasan pengertian tiga kata tersebut, dapat disimpulkan bahwapenelitian tindakan kelas merupakan suatu pencermatan terhadap kegiatan yang sengaja dimunculkan, dan terjadi dalam sebuah kelas.

Desain Penelitian ini Penelitian tindakan kelas ini menggunakan model Kemmis dan Mc Taggart modifikasi yang menggunakan sistem spiral refleksi diri yang dimulai dengan rencana, tindakan, pengamatan, refleksi, perencanaan kembali merupakan dasar untuk suatu ancangancang pemecahan masalah.

Model tersebut dapat dilihat pada gambar berikut:

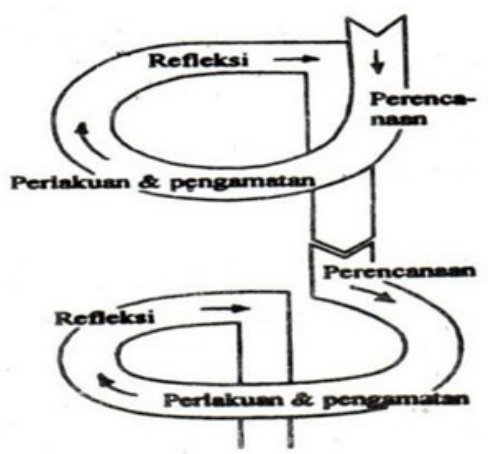

Gambar 1. Desain Penelitian model Kemmis dan Mc Taggart 


\section{HASIL DAN PEMBAHASAN}

\section{Siklus I}

\section{Perencanaan Tindakan pada Siklus I}

Pada penelitian tindakan kelas ini pengambilan data siswa dikakukan dalam beberapa kali pertemuan proses belajar mengajar. Hal tersebut dilakukan agar tindakan yang dilaksanakan akan mendapatkan hasil yang maksimal. Berdasarkan permasalahan pada pratindakan diatas, peneliti mencoba memecahkannya menggunakan media gambar Flash Card dengan pendekatan saintifik di SDN 13 Kapalo Koto

Rencana tindakan pada siklus pertama yaitu: 1) Pemilihan model pmbelajaran Talking Stick pada materi menulis kalimat petunjuk secara sederhana. 2) peneliti menetapkan waktu pelaksanaan tindakan yaitu 1 kali dalam satu minggu, di SDN 13 Kapalo Koto. 3) Membuat instrument. 4) Melakukan penelitian.

\section{Pelaksanaan Tindakan pada Siklus I}

Proses pembelajaran diawali dengan apersepsi yakni peneliti menayakan kata sapaan yang siswa lakukan setiap pagi di sekolah saat bertemu dengan guru, "Selamat pagi pak" , "Hallo pak". Kemudian peneliti mengajak siswa mengamati video kata sapaan yang ditampilkan oleh guru melalui power point di depan kelas. Siswa diminta secara bergantian, bermain peran membacakan dongeng fabel dengan melakukan percakapan di depan kelas.

Siswa mendengarkan penjelaskan dari peneliti tentang materi menulis permulaan menggunakan gambar Flash Card, siswa bertanya jawab dengan guru terkait menulis kalimat sapaan menggunakan gambar Flash Card tema fabel. Siswa diminta menyusun gambar Flash Card tema fabel yang telah dibagikan oleh guru di dalam LKPD.

Dengan melihat gambar Flash Card tema fabel dan bimbingan peneliti, siswa diminta menuliskan kalimat kata sapaan didalam LKPD yang dibagikan oleh peneliti. Setelah selesai siswa dimintamengemukakan kalimat kata sapaan yang telah ditulis didalam LKPD di depan kelas. Seluruh siswa mengumpulkan hasil menulis kalimat kata sapaan kepada peneliti untuk dikoreksi untuk mengetahui pemahaman peserta didik, peneliti melakukan evaluasi dengan memberikan soal evaluasi kepada peserta didik.

\section{Observasi Siklus I}

Tabel 1.Deskripsi Hasil Observasi Siswa dalam Pembelajaran Menulis Permulaan menggunakan Media Gambar dengan pendekatan saintifik pada Siklus I.

\begin{tabular}{|c|c|c|c|}
\hline Keterangan & Saintifik & $\begin{array}{r}\text { Presentasi } \\
\text { Keberhasilan }\end{array}$ & Rata-rata \\
\hline \multirow{5}{*}{ Pertemuan 1} & Mengamati & 76.92 & \multirow{5}{*}{67.00} \\
\hline & Menanya & 58.65 & \\
\hline & Mencoba & 74.03 & \\
\hline & Menalar & 58.65 & \\
\hline & Mengkomunikasikan & 65.38 & \\
\hline \multirow{5}{*}{ Pertemuan 2} & Mengamati & 75.96 & \multirow{5}{*}{75} \\
\hline & Menanya & 72.11 & \\
\hline & Mencoba & 77.88 & \\
\hline & Menalar & 75.00 & \\
\hline & Mengkomunikasikan & 74.03 & \\
\hline
\end{tabular}

Berdasarkan tabel di atas siswa sudah mulai aktif dalam mengikuti pembelajaran menulis permulaan. Dengan meningkatnya keaktifan siswa selama mengikuti pembelajaran menulis permulaan, maka hasil evaluasinya meningkat.

Dalam penggunaaan media gambar Flash Card dengan pendekatan saintifik terdapat data hasil perolehan nilai siswa yang dapat disajikan oleh peneliti. Berikut disajikan deskripsi hasil evaluasi menulis permulaan pada siklus $\mathrm{I}$. 
Tabel 2. Deskripsi Kemampuan Menulis Permulaan padaSiklus I

\begin{tabular}{|c|c|c|}
\hline \multirow{2}{*}{ Keterangan } & \multicolumn{2}{|c|}{ Siklus I } \\
\cline { 2 - 3 } & Pertemuan 1 & Pertemuan 2 \\
\hline $\begin{array}{c}\text { Jumlah siswa yang } \\
\text { mencapai KKM }\end{array}$ & 11 & 17 \\
\hline Dalam persen (\%) & 42,30 & 65,38 \\
\hline Rata-rata nilai siswa & 67,11 & 74,46 \\
\hline Rata-rata & \multicolumn{2}{|c}{71,00} \\
\hline
\end{tabular}

\section{Refleksi}

Berdasarkan hasil observasi kendala-kendala yang dialami siswa adalah sebagai berikut; (1). Pemahaman siswa terhadap gambar Flash Card dirasa kurang maksimal, (2). Sebagian siswa belum mampu mengembangkan tulisannya, sehingga hanya dua atau tiga kalimat yang dapat ditulisnya dan hanya mengacu pada menyebutkan kata sapaan. (3). Gambar Flash Card yang disajikan peneliti dirasa siswa kurang jelas. (4). Sebagian siswa belum menggunakan ejaan yang benar. (5). Sebagian siswa belum menyusun kalimat dengan benar. (6). Sebagian siswa belum dapat memadukan kalimat dengan baik.

Permasalahan - permasalahan tersebut harus segera diatasi agar kemampuan menulis siswa dapat ditingkatkan secara maksimal melalui penggunaan media gambar Flash Card dan dengan pendekatan saintifik. Dalam mengatasi masalah tersebut peneliti harus cermat, karena jika permasalahan tersebut tidak dapat teratasi maka akan menghambat pelaksanaan tindakan berikutnya.

Melihat hasil dari evaluasi ataupun observasi terhadap siswa pada siklus I terdapat kenaikan kemampuan siswa dalam menulis, Hal tersebut terlihat dari meningkatnya jumlah siswa yang telah mencapai KKM yang telah ditetapkan. Namun jumlah tersebut belum memenuhi target peneliti yakni minimal $80 \%$ peserta didik dapat mencapai KKM. Oleh sebab itu peneliti merencanakan perbaikan tindakan yang akan dilakukan pada siklus kedua.

\section{Siklus II}

\section{Perencanaan Siklus II}

Siklus II merupakan tindak lanjut dari hasil refleksi pada siklus I.Mengingat masih terdapat berbagai kendala yang terjadi pada siklus I,maka peneliti membuat rencana perbaikan sebagai berikut.

1) Peneliti berdiskusi dengan teman sejawat mengenai kendala- kendala yang terjadi pada siklus I.

2) Peneliti mencari gambar Flash card yang lebih jelas dan menarikagar siswa lebih mudah mengidentifikasi gambar yang ada.

3) Peneliti lebih memperhatikan peserta didik selama proses pembelajaran, yakni dengan lebih intensif menghampiri siswasehingga jika ada peserta didik yang kesulitan peneliti langsung dapat membantu.

4) Peneliti lebih membimbing siswa untuk memahami gambar. Flash Card dalam membuat kalimat kata sapaan.

5) Peneliti memberikan teks cerita bermain peran menggunakan kalimat kata sapaan, yang diharapkan dapat membantu siswa dalam menyusun kalimat.

6) Peneliti selalu mengingatkan siswa untuk menggunakan ejaan yang benar.

\section{Tindakan siklus II}

Berdasarkan data yang ada, rata-rata hasil evaluasi menulis permulaan tindakan siklus I mengalami peningkatan dari pada pratindakan. Dari setiap pertemuannya, siklus I juga mengalami peningkatan. Akan tetapi standar keberhasilan yang digunakan peneliti yakni $80 \%$ dari jumlah peserta didik mencapai KKM. Sedangkan pada siklus I, baru $71,00 \%$ dari jumlah peserta didik yang mencapai KKM. 
Peneliti meminta siswa mengamati gambar kata sapaan keberagaman dari daerah asal yang ditampilkan oleh guru melalui power point didepan kelas.Siswa bertanya jawab dengan peneliti terkait keberagaman suku dari daerah asal yang telah dilihat oleh siswa didepan kelas. Kemudian peneliti meminta siswa mengamati tayangan video keberagaman disekolah, yang ditampilkan oleh peneliti didepan kelas. Siswa mendengarkan penjelasan peneliti tentang kata sapaan. Siswa diminta oleh peneliti secara bergantian, bermain peran membacakan dialog percakapan kata sapaan dengan materi keberagaman di depan kelas. Setelah selesai melakukan percakapan didepan kelas, siswa mendengarkan penjelaskan dari peneliti tentang materi menulis permulaan menggunakan gambar Flash Card.

Siswa mendengarkan penjelasan guru tentang membuat kalimat sapaan dan menentukan kata sapaan menggunakan media gambar Flash Card tema keberagaman. Siswa bertanya jawab dengan guru terkait menulis kalimat sapaan menggunakan Flash Card dan menentukan kata sapaan pada kalimat. Siswa diminta menyusun gambar Flash Card yang telah dibagikan oleh guru di dalam LKPD.

Dengan melihat gambar Flash Card dan bimbingan guru, siswa diminta menuliskan kalimat kata sapaan danmenentukan kata sapaan didalam LKPD yang dibagikan oleh guru. Setelah selesai peserta didik diminta mengemukakan kata sapaan yang telah ditulis didalam LKPD didepan kelas. Setelah itu penelitimemberikan soal evaluasi kepada siswa. Soal evaluasi tersebut dikerjakan secara individu. Setelah semua siswa selesai mengerjakan evaluasi, peneliti meminta siswa mengumpulkan hasil evaluasi yang telah dikerjakannya.

\section{Observasi siklus II}

Deskrisip hasil observasi peserta didik selama mengikuti pembelajaran menulis permulaan menggunakan media gambar Flash Card dengan pendekatan saintifik adalah sebagai berikut.

Tabel 3.Deskripsi Hasil Observasi Siswa dalam Pembelajaran Menulis Permulaan menggunakan Media Gambar dengan pendekatan saintifik pada Siklus II.

\begin{tabular}{|c|c|c|c|}
\hline Keterangan & Saintifik & $\begin{array}{r}\text { Presentasi } \\
\text { Keberhasilan }\end{array}$ & Rata-rata \\
\hline \multirow{5}{*}{ Pertemuan 1} & Mengamati & 85.57 & \multirow[b]{5}{*}{86.00} \\
\hline & Menanya & 76.92 & \\
\hline & Mencoba & 88.46 & \\
\hline & Menalar & 86.53 & \\
\hline & Mengkomunikasikan & 91.34 & \\
\hline
\end{tabular}

Dari data di atas dapat disimpulkan bahwa keaktifan peserta didik dalam mengikuti pembelajaran menulis permulaan menggunakan media gambar Flash Card dengan pendekatan saintifik. Pada siklus II lebih meningkat. Keaktifan peserta didik dalam mengikuti pembelajaran menulis permulaan tersebut berimplikasi pada peningkatan rata-rata hasil evaluasi siswa pada siklus II.

Dalam penggunaaan media gambar Flash Card dengan pendekatan saintifik terdapat data hasil perolehan nilai siswa yang dapat disajikan oleh peneliti. Berikut disajikan deskripsi hasil evaluasi menulis permulaan pada siklus II.

Tabel 3.Deskripsi Kemampuan Siswa Dalam Menulis Permulaan pada Siklus II

\begin{tabular}{|c|c|}
\hline Keterangan & Siklus II \\
\cline { 2 - 2 } & Pertemuan 1 \\
\hline $\begin{array}{c}\text { Jumlah siswa yang } \\
\text { mencapai KKM }\end{array}$ & 22 \\
\hline Dalam persen (\%) & 84,61 \\
\hline Rata-rata nilai siswa & 82,03 \\
\hline
\end{tabular}


Dari tabel diatas dapat dilihat bahwa pada siklus II ini terdapat peningkatan. Pada pertemuan pertama siswa yang mencapai KKM sebanyak 22 siswa atau $84,61 \%$ dari jumlah 26 siswa. Berarti hanya 4 siswa yang belum mencapai KKM. Dengan demikian pembelajaran menulis permulaan tema keberagaman menggunakan media gambar Flash Card dan pendekatan saintifik tersebut dapat dikatakan berhasil.

Jika dilihat dari rata-rata nilai menulis permulaan sudah mengalamipeningkatan yaitu sudah mencapai $82.03 \%$ Dari rata-rata tersebut sudahmelampaui KKM yang telah ditetapkan yakni 80. Jadi bisa dikatakan bahwa pembelajaran tesebut berhasil.

\section{Refleksi}

Tahap empat pada siklus II ini adalah refleksi. Pada tahap ini peneliti mengevaluasi implementasi tindakan dan menganalisis dampak implementasi tindakan yang telah dilakukan. Kegiatan tersebut dilakukan untuk mengetahui sejauh mana media gambar Flash Card dan pendekatan saintifik dapat mempengaruhi peningkatan kemampuan menulis permulaan siswa pada siklus II. Melihat data yang ada, media gambar Flash Card dan pendekatan saintifik dapat meningkatkan kemampuan menulis permulaan siswa materi pokok menulis kalimat kata sapaan tema keberagaman.

\section{Pembahasan}

peningkatan kemampuan menulis permulaan pada siswa kelas II SDN 13 Kapalo Koto, Padang, Sumatera Barat setelah dilakukan Penelitian Tindakan Kelas. Uraian yang akan disampaikan adalah mengenai kemampuan siswa pada pembelajaran menulis permulaan sebelum dilakukan tindakan, pelaksanaan tindakan pada setiap siklus, dan peningkatan kemampuan menulis permulaanpeserta didik melalui penggunaan media gambar Flash Card dan pendekatan saintik.

\section{Peningkatan Kemampuan Menulis Permulaan Siswa Menggunakan Media Gambar dengan Pendekatan Saintifik.} siklus II.

Berikut disajikan data peningkatan rata-rata nilai evaluasi siswa dari pra tindakan sampai

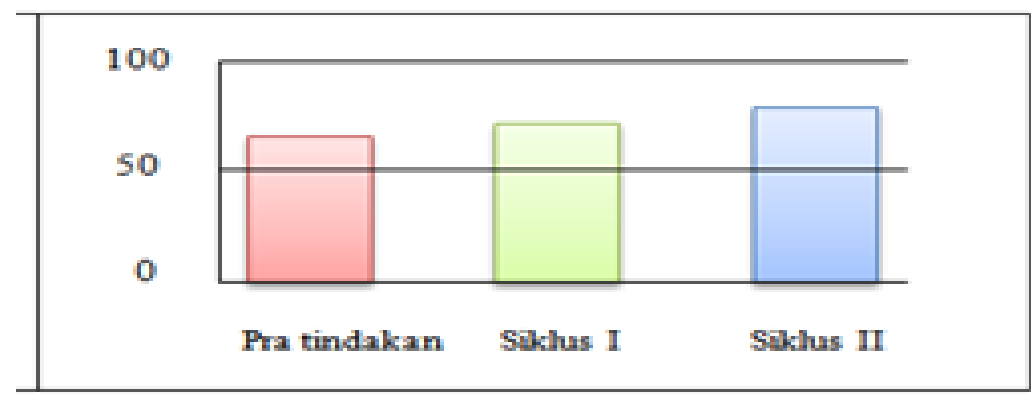

\section{Diagram 1. Peningkatan Rata-Rata Nilai Hasil Evaluasi peserta didik}

Dari data di atas dapat dilihat bahwa terdapat peningkatan rata- rata siswa pada setiap siklusnya. Dari pra tindakan ke siklus I mengalami peningkatan rata-rata menulis permulaan siswa sebesar 9,85.Dari siklus I ke siklus II juga mengalami peningkatan sebesar 11,03. Dengan demikian dapat disimpulkan penggunaan media gambarFlash Card dengan pendekatan keterampilan saintifik terbukti dapat meningkatkan kemampuan siswa dalam menulis permulaan materi pokok menulis kalimat kata sapaan tema keberagaman.

Kemampuan awal siswa dalam pembelajaran menulis permulaan dapat dilihat dari hasil tes pra tindakan. Dari hasil penelitian mengenai data awal, kemampuan menulis permulaan siswa kelas II SDN 13 Kapalo Koto masih terhitung rendah. Hal itu terlihat dari rata-rata hasil tes menulis permulaan yang dilakukan pada pra tindakan sebesar 61,15. Berbagai faktor yang menjadi penyebab rendahnya kemampuan menulis permulaan di kelas II. Diantaranya adalah pada tahap menulis permulaan sebelumnya yakni di kelas 1 SD siswa belum diajarkanuntuk mengungkapkan idenya ke dalam tulisan. Mereka baru terbiasa merangkai huruf menjadi kata atau kalimat saja, 
belum terbiasa memahami apa yang ditulisnya. Mengingat uraian di atas, guru selaku peneliti melakukan tindakan perbaikan pada proses pembelajaran menulis permulaan tersebut. Pelaksanaann tindakan siklus I diharapkan dapat meningkatkan kemampuan peserta didik dalam menulis permulaan.

Peningkatan kemampuan menulis permulaan pada pasca tindakan siklus I ini ditunjuk kan dari rata-rata hasil evaluasi siswa. Pada pra tindakan rata-rata menulis permulaan siswa yakni 61,15 . Pada siklus I, pada pertemuan pertama rata - rata menulis permulaan siswa adalah 67,11 . Rata-rata siswa pada pertemuan ke dua adalah 74,46. Dari hasil tersebut terlihat bahwa terdapat peningkatan rata-rata hasil evaluasi menulis permulaan siswa pada setiap pertemuannya.

Meskipun pada tindakan siklus I mengalami peningkatan, namun belum memenuhi target peneliti yakni $80 \%$ peserta didik mampu mencapai KKM. Pada tindakan siklus I ini peneliti masih mengalami berbagai kendala. Jumlah siswa yang mencapai KKM mengalami peningkatan sebesar $11,46 \%$ dari $27 \%$ menjadi $38,46 \%$. Rata-rata nilai menulis permulaan siswa pada siklus I ini mengalami peningkatan sebesar 9,85. Dari uraian di atas menunjukkan bahwa tindakan siklus I dirasa belum maksimal. Berdasarkan analisa peneliti hal tersebut disebabkan oleh beberapa faktor. Faktor - faktor tersebut antara lain Pemahaman siswa terhadap gambar Flash Card dirasa kurang maksimal, Sebagian siswa belum mampu mengembangkan tulisannya, sehingga hanya dua atau tiga kalimat yang dapat ditulisnya dan hanya mengacu pada menyebutkan kata sapaan.

Pada siklus II peneliti melakukan beberapa perbaikan dalam proses pembelajaran. Pada setiap pertemuannya pun terdapat peningkatan rata-rata nilai menulis permulaan siswa. Rata-rata nilai evaluasi menulis permulaan siswa pada siklus I pertemuan pertama adalah 67,11 . Pada pertemuan kedua rata-rata menulis permulaan siswa yakni 74,46. Pada siklus II ini, pada pertemuan 1 rata-rata nilai evaluasimenulis permulaan mengalami peningkatan dengan nilai siswa menjadi 82,03. Dan jumlah nilai siswa yang mencapai KKM adalah 84,61. Data tersebut menunjukkanbahwa pada siklus II ini terjadi peningkatan rata-rata menulis permulaan siswa sudah mencapai nilai KKM 80\%.

\section{SIMPULAN}

Kemampuan menulis permulaan siswa sebelum adanya tindakan masih rendah. Hal tersebut disebabkan disebabkan karena tahap berpikir siswa masih dalam tahap operasional konkret, namun materi yang disampaikan guru masih terkesan abstrak, sehingga sulit dipahami siswa. Pada siklus I, peserta didik yang mencapai KKM belum ada $80 \%$. Hal tersebut disebabkan karena siswa kurang cermat dalam menganalisis gambar Flash Card. Gambar Flash Card. yang disajikan peneliti juga dirasa peserta didik kurang jelas. Dalam menyusun gambar Flash Card pun siswa masih dibimbing dan di arahkan. Pada siklus II peneliti melakukan perbaikan sesuai masalah yang ditemukan pada siklus $\mathrm{I}$.

Berdasarkan hasil penelitian yang telah dilakukan, dapat disimpulkan bahwa penggunaan media gambar Flash Card. denganpendekatan saintifik dapat meningkatkan kemampuan menulis permulaan siswa kelas 2 SD materi menulis kalimat kata sapaan tema fabel dan keberagaman secara sederhana dengan bahasa tulis. Hal itu dibuktikan dari hasil tes menulis permulaan siswa pada pra tindakan nilai siswa yang mencapai KKM hanya $27 \%$. Sedangkan rata-rata nilainya yakni 61,15 . Pasca tindakan siklus I, nilai siswa yang mampu mencapai KKM meningkat menjadi 38,46\%. Rata-rata nilai siswa juga meningkat menjadi 71,00. Sedangkan setelah tindakan siklus II siswa yang mencapai KKM sebanyak $84,61 \%$. Rata-ratanya nilai menulis permulaan pada siklus II meningkat lagi menjadi 82,03.

\section{DAFTAR PUSTAKA}

Ahmad Rofi'uddin \& Darmiyati Zuhdi.(1998/ 1999).Pendidikan Bahasa Dan Sastra Indonesia Di Kelas Tinggi. Jakarta: Departemen pendidikan Nasional Direktorat Jenderal Pendidikan Tinggi.

Daryanto, Hamid. 2014. Pendekatan Pembelajaran Saintifik Kurikulum2013.

Yogyakarta: Gava Media

Fatoni, 2009. Media pembelajaran. Yogyakarta: Pustaka Pelajar

Nurcahyanti, I., \& Umar Samadhy, F. (2014). Peningkatan Keterampilan 
Menulis Permulaan Melalui Metode Sas Dengan Media Papan Selip. Joyful Learning Journal, 3(4).

Nuryamah, I., \& Sunarya, D. T. (2016). Upaya Meningkatkan KeterampilanMenulis Permulaan dalam Melengkapi Cerita Rumpang Menggunakan Media Gambar dan Papan Bergaris. Jurnal Pena IImiah, 1(1), 761-770.

Sugiyono. (2009). Metode Penelitian Kuantitatif, Kualitatif, dan R \& D. Bandung: Alfabeta.

Arikunto, Suharsimi. 2007. Manajemen Penelitian. Rineka Cipta. Jakarta.

Susanto, Ahmad. 2013. Teori Belajar dan Pembelajaran di Sekolah Dasar.Jakarta: Prenada Media Group. 